\title{
Energy Use Pattern in Millet Production in Semi-Arid Zone of Nigeria
}

\author{
Mohammed Shu'aibu Abubakar \\ Department of Agricultural Engineering Bayero University, Kano \\ Nigeria
}

\section{Introduction}

Agriculture is an important economic sector in Nigeria, although the country depends heavily on the oil industry for its budgetary revenues. Approximately 70 percent of the population engages in agricultural production at a subsistence level. Even though, the agriculture related activities holdings are generally small scale. Agriculture provided 41 percent of Nigeria's total gross domestic product (GDP) in 1999. This percentage represented a normal decrease of 24.7 percent from its contribution of 65.7 percent to the GDP in 1957. The decrease will continue because of the fact that when economic development occurs, the relative size of the agricultural sector usually decreases (Abdullahi et al., 2006). Nigeria's wide range of climate variations allows it to produce a variety of food crops. The staple food crops include cassava, yams, sweet potatoes, coco-yams, corn, cowpeas, beans, millet, rice, wheat, sorghum, and a variety of fruits and vegetables. Efficient use of energy is one of the principal requirements of sustainable agriculture. Energy use in agriculture has been increasing in response to increasing population, limited availability of arable land, and a desire for higher standards of living. Therefore, energy is one of the most valuable inputs in agricultural production. It is invested in various forms such as mechanical (farm machines, human power, and animal draft), chemical fertilizer (pesticides and herbicides) and electrical. The amount of energy used in agricultural production, processing and distribution needs to be adequate in order to feed the rising population and to meet other social and economic goals (Stout, 1990). Because of the subsistence nature of the millet production in the study area, most of farmers mainly produce the crop using only manual energy. Very few farmers use tractors for tillage during the land preparation stage. Apart from this single mechanical energy use, all other farm operations are executed using manual energy or animal traction. This trend of limited mechanisation is common to other crops grown in the country. Therefore, less energy input has being the case crop production like millet. Because of the lack of data on energy expenditure and benefits associated with energy analysis in the production of millet. Also information on comparative use of different energies is also lacking. And most of the producers do not have enough knowledge on the most efficient energy inputs. Consequently, it is neither possible to identify viable energy inputs and options in the production process nor plan for their conservation. Under these situations, an input-output energy analysis provides planners and policy makers an opportunity to evaluate economic interactions of energy use. This information is required in 
order to make deductions on the efficiencies of the energies and suggestions on which energy sources or their combinations need to be used and at what levels. Also this would serve as a data bank for any related study.

\section{Energy input-output analysis in crop production}

Some studies on energy use and evaluation methods elsewhere were reported. Bridges and Smith (1979) developed a method for determining the total energy input for agricultural practices. The categories of energy considered were those of manufacture, transport and repairs (MTR), fuel and labour. Fluck (1985) also in his study developed two models to quantify energy sequestered in repairs and maintenance of agricultural machinery as compared with the energy input in new machinery. Energy use analysis from the literature have shown that different authors who used different methods for evaluating human energy reported several values of the energy content for manual labour. Hence, there is no universally accepted energy value of manual labour. However, for countries where agriculture is dominated by human energy, it is reasonable to adopt the value obtained by Norman (1978). Sustainable direct energy is required to perform various tasks related to crop production processes such as for land preparation, irrigation, harvest, post harvest processing, transportation of agricultural inputs and outputs. In other word, high level of direct energy such as fuel and electricity are needed to be used at farm for crop production (Alam et al., 2005; Hoeppner et al., 2006; Khambalkar et al., 2005; Kizilaslan, 2009). Unlike direct energy which is directly consumed at the farm, indirect energy is not directly consumed at the farm rather are the energy used in the manufacture, packaging and transport of fertilizers, seeds, machinery production and pesticides (Ozkan et al., 2004). The energy input for the crop production differs to a large extent from area to area and also depending on the level of mechanization. In modern crop production is characterized by the high input of fossil energy (fuel and electricity) which is consumed as direct energy and as indirect energy (fertilizers, pesticides, machinery, etc.). In some low-input farming systems, example in large areas of Africa, the energy input on arable land is lower than 1GJ ha-1, whereas in some modern high-input farming systems in west Europe, it can exceed 30GJ ha-1 $^{-1}$ (Pimentel, 2009; Reed et al., 1986). In the past decade, with increase in energy inputs in agriculture, an equivalent increase in crop yields occurred. Other studies have suggested that the energy use efficiency of our traditional cropping systems have been sharply going downward in recent years due to energy inputs increasing faster than energy output as a result of the growing dependency on inorganic fertilizers and fossil fuels (Hatirli et al., 2006; Jekayinfa \& Bamgboye, 2007; Khambalkar et al., 2005). If the increase in the energy use in the agricultural industry continues, the only chance of producers to increase total output will be using more input as there is no chance to expand the size of arable lands. Under these circumstances, an input-output analysis provides planners and policy-makers an opportunity to evaluate economic interactions of energy use.

\section{Millet production}

Pearl millet (Pennisetum glaucum (L) R. Br.) is a cereal grain with good drought tolerance and hardiness widely grown in the hot and dry climates areas of arid and semi-arid regions of Africa and southern Asia. It is one of the four most important cereals crop (millets, sorghum, 
maize and rice) normally grown where rain fall is not sufficient (200-600 $\mathrm{mm}$ ) for corn and sorghum. In 1995, the global production of millet exceeds 10 million tons per year in a total estimated area of 15 and 14 million hectares in Africa and Asia respectively. Millet production increased from 26 million tonnes in 1981 to 31 million tones in 1990 in Asia, Africa and the former USSR. The major millets producers' nations in 1990 were India (15\%), China (10\%), Nigeria (65\%) and the former USSR (10\%) (FAO, 1996). Amongst different species of millet Worldwide, four are cultivated in Africa with Pearl millet-Pennisetum glaucum (L) R. Br., Finger millet-Eleusine coracana L. Gaertn., Teff millet-Eragrostis teff (Zucc) and Fonio millet-Digitaria exilis (acha) accounting for $76 \%, 21 \%, 1.8 \%$ and $0.8 \%$ of the total production respectively (Andrews \& Kumar, 1992). In most countries of Africa and Asia, millets production is primarily for human consumption as staple food (78\%) with other uses of less than 20\%. In other countries like Mexico, Australia, Canada and the United State of America, pearl millet is grown as a forage crop for livestock production. Future trends indicate that millet crop production will increase globally because of the increase in number of millet consumers. However, the production of millets is still at subsistence level by smaller scale farmers (0.5-5 hectare farm size) in most part of the Africa. Furthermore, millet crops remain the key sources for food security and energy for about 250 million people in sub-Saharan Africa. Meanwhile, the millets crop production areas in this region of subSaharan Africa coincide with where most of the poor people live. This coincidence has a significant effect on these poor people to their socio-economic, food/shelter, health and environment. In Nigeria, like any of the sub-Saharan African countries, millet is produced in rid and semi-arid drought-prone northern part by the low income earners farmers. Sufficient energy is needed in the right form and at the right time for adequate crop production. One way to optimize energy consumption in agriculture is to determine the efficiency of methods and techniques used. With the current increase in world population, energy consumption needs effective planning. That is, the input elements need to be identified in order to prescribe the most efficient methods for controlling them

\section{Study area}

A study on the pattern of energy use in millet production was conducted in the eight local government areas of Jigawa States semi-arid zone of Nigeria (Figure 1). It is situated in north-western part of the country between Latitudes $11.00 \mathrm{\circ}$ to $13.00 \mathrm{o}$ and Longitudes $8.00^{\circ} \mathrm{E}$ to $10.15^{\circ} \mathrm{E}$. The study areas have $3-4$ months rainfalls duration followed by a long dry session. The annual precipitation is between 400 and $600 \mathrm{~mm}$, which vary from year to year. The main livelihood of the people is agriculture of which millet is the most important crop for consumption. Over eighty percent of the population is engaged in subsistence farming and animal husbandry.

A stratified random sampling technique was used to select the millet farmers in the study area and were classified into three groups (I-III) based on their farm sizes as small (1 ha or less), medium (2-4 ha) and large farms (5 ha and more). Sixty (60) farmers were interviewed in each of the groups. A total of 180 sample data were collected. The data for energy input resources used in all the selected farms during millet production from land preparation up to transportation to market or house were collected using structural questionnaire and oral interviews in the production years 2006 and 2007. 


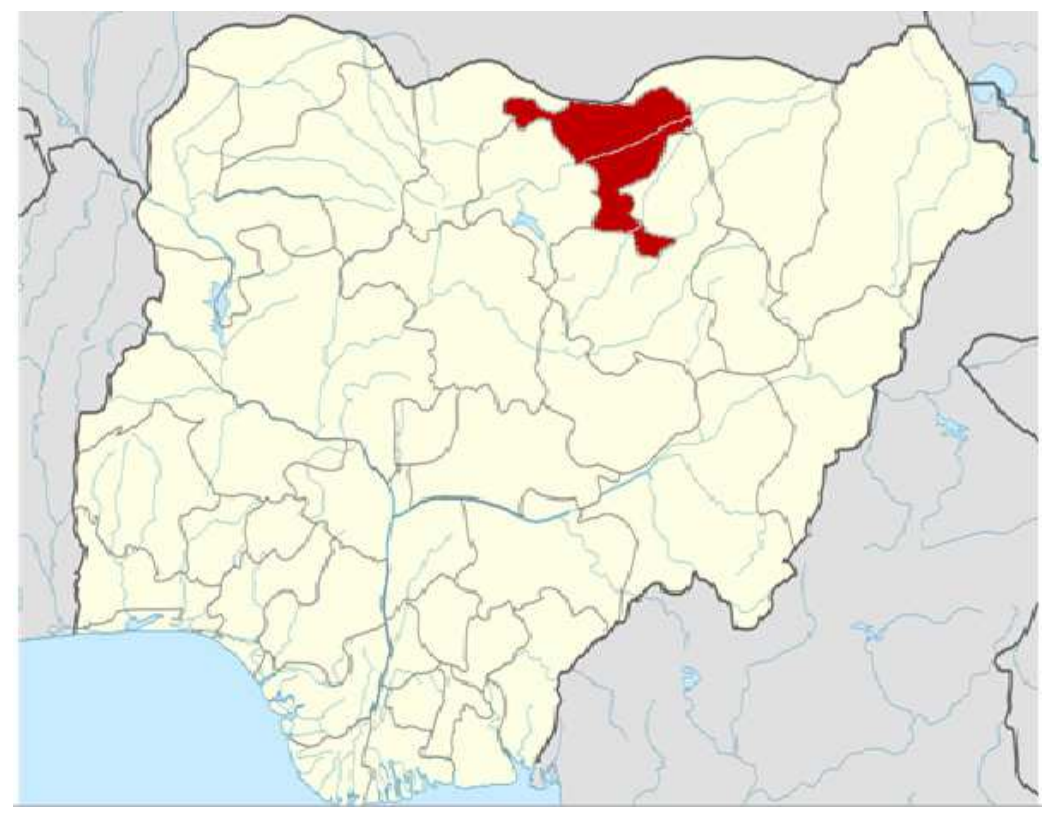

Fig. 1. Map of the study area

\section{Energy use pattern in millet production}

Substantial numbers of research studies have been conducted on energy use in agriculture (Abubakar \& Ahmad, 2010; Ahmad, 1994; Canakci \& Akinci, 2006; Hatirli et al., 2006; Hoeppner et al., 2006; Kizilaslan, 2009). Energy use in agricultural production has become more intensive due to the use of fossil fuel chemical fertilizers, pesticides, machinery and electricity to provide considerable increases in food production. However, more intensive energy use has brought some important human health and environment problems so efficient use of inputs has become important in terms of sustainable agricultural production. However, millet has been paid relatively little attention. Furthermore, this study considered the effect of farm size on energy use and input costs. According to Pimentel (1992), energy consumption per unit area in agriculture is directly related to the development of the technology in farming and the level of production. The amount of energy used in agricultural production, processing and distribution is prerequisites for improved agricultural production. Fluck and Baird (1980) hypothesized that the highest partial energy productivity is achieved at the point of minimum mechanization energy inputs and increasing mechanization energy increase crop yield at a decreasing rate.

\subsection{Evaluation of energy use}

The input energy consumption for different farm field operations in producing millet was classified on the basis of source and use as direct and indirect energy and then renewable and non-renewable energy. The direct energies such as human or animal power, diesel and electricity, are the energy which are released directly from power sources in millet 
production while indirect energy are those which are dissipated during various conversion processes like energy consumed indirectly in manufacturing, repair and transport, storage, distribution and related activities and also energies embodied in seeds, farmyard manure, pesticides and fertilizers. Non-renewable energy includes petrol, diesel, electricity, chemicals, fertilizers and renewable energy consists of human and animal power (Pimentel, 1992; Singh et al., 2002, 2003; Singh et al., 2007).

\subsubsection{Direct energy inputs}

The direct energy inputs per hectare during millet production include manual (human) labour, draft animal and fuel (diesel) and were computed using the equations adopted by Bockari-Gevao et al., (2005) in equations below as follows;

\subsubsection{Energy input from manual labour}

The rate of labour use in the millet production process was determined for each operation. The labour energy input ( $\left.\mathrm{MJ} \mathrm{ha}^{-1}\right)$ at every stage of the production process was estimated by the following equation 2;

$$
M E_{\text {labour }}=\frac{\text { NLabour X Time }}{\text { Area }} X \text { FLabour }
$$

where:

$\mathrm{ME}_{\text {labour }}=$ Manual labour energy, $\mathrm{MJ} \mathrm{ha}^{-1}$

NLabour $=$ Number of working labourers

Time $=$ Operating time, $\mathrm{h}$

Area $=$ Operating area, ha

FLabour $=$ Labour energy factor, $\mathrm{MJ} \mathrm{h}^{-1}$

\subsubsection{Energy input from draft animal}

Singh et al.,(1997) reported that pair of bullocks have power equivalent of $746 \mathrm{~W}$ (1.0 hp). Therefore Energy input from draft animal was evaluated as follow;

$$
E_{D A}=\frac{W}{\text { Area }}
$$

where:

$\mathrm{E}_{\mathrm{DA}}=$ Draft animal energy input, $\mathrm{MJ}$ ha-1

$\mathrm{W}=$ Power equivalent for pair of bullocks, $\mathrm{MJ}$

Area $=$ Operation area, ha

\subsubsection{Energy input from fuel}

The specific energy use from fuel (fossil) was evaluated by quantifying the amount of diesel consumed during each millet production process

$$
S_{D F E}=A F U X P E U X N P X h
$$

where:

$\mathrm{S}_{\mathrm{DFE}}=$ Specific direct energy use (fuel) for a field operation, $\mathrm{MJ} \mathrm{ha}^{-1}$

$\mathrm{AFU}=$ Average quantity of fossil fuel (diesel or petrol) use per working hour, $\mathrm{L} \mathrm{h}^{-1}$

$\mathrm{PEU}=$ Specific energy value per unit litre of fuel, $\mathrm{MJ} \mathrm{L}^{-1}$

$\mathrm{NP}=$ Number of pass for applications in the considered field operation 
$\mathrm{h}=$ Specific working hours per pass, $\mathrm{h}$ ha-1

\subsubsection{Indirect energy inputs}

The indirect energy inputs per hectare during millet production include machinery, seed, fertilizer and pesticide and were computed using the equations adopted by Bockari-Gevao et al., (2005) in equations below as follows;

\subsubsection{Energy input from machinery}

The indirect energy contribution of machinery for each field operation was determined by the following equation 4 below;

$$
S_{I N D M E}=\frac{T M W X C M E D}{S V} \times N P X h
$$

where:

$\mathrm{S}_{\text {INDME }}=$ Specific indirect energy for machinery use for a field operation, $\mathrm{MJ}$ ha-1

TMW $=$ Total weight of the specific machine, $\mathrm{kg}$

$\mathrm{CMED}=$ Cumulative energy demand for machinery, $\mathrm{MJ} \mathrm{kg-1}$

$\mathrm{SV}=$ Salvage value life of machinery, $\mathrm{h}$

$\mathrm{NP}$ and $\mathrm{h}$ as defined above.

\subsubsection{Energy input from chemical energy}

The indirect chemical energy per unit area for other production inputs such as fertilizer, pesticides and farmyard manure was expressed as in equation 5 below;

$$
I N D E_{S F P}=\text { Rate X ENFMaterial }
$$

where:

$\mathrm{INDE}_{\mathrm{SFP}}=$ Indirect energy input such as for seed, fertilizer or pesticides, $\mathrm{MJ}$ ha-1

Rate $=$ Application rate of input, $\mathrm{kg} \mathrm{ha}^{-1}$

ENFMaterial $=$ Energy factor of material used, $\mathrm{MJ} \mathrm{kg}^{-1}$

\subsubsection{Energy input from biological energy}

Mainly seeds and hormone were included as biological energy inputs. Existing data on hormones was used. The energy equivalent value of $14.00 \mathrm{MJ} \mathrm{kg}^{-1}$ was used for seed (millet) input and an assumed equivalent value higher than energy (seed) input by $1 \mathrm{MJ} \mathrm{kg}^{-1}$ of crop (millet) production output was also used (Singh \& Mittal, 1992; Singh et al., 1997).

\subsubsection{Total energy inputs}

The energy input intensity $\left(\mathrm{e}_{\mathrm{I}}\right)$ was determined from the summation of all the energies input (direct and indirect) and dividing by the effective area of millet production as given by the following equation 6 below;

$$
e_{I}=\frac{E}{A}
$$

where:

$\mathrm{e}_{\mathrm{I}}=$ Energy input intensity, $\mathrm{MJ} \mathrm{ha}^{-1}$

$\mathrm{E}=$ Total energy consumption, $\mathrm{MJ}$

$\mathrm{A}=$ The effective production area, ha 


\subsubsection{Total energy output}

The energy output intensity $\left(\mathrm{e}_{\mathrm{O}}\right)$ was derived by multiplying the production intensity $(\mathrm{s})$ by the energy coefficient of seed $\left(B_{s}\right)$ as represented in equation 7 ;

$$
e_{o}=s X B_{s}
$$

where:

$\mathrm{e}_{0}=$ Energy output intensity, $\mathrm{MJ}$ ha ${ }^{-1}$

$\mathrm{s}=$ Production intensity, $\mathrm{kg}$ ha

$\mathrm{B}_{\mathrm{s}}=$ Energy coefficient of seed (millet), $\mathrm{MJ} \mathrm{kg}^{-1}$

\subsubsection{Energy use ratio}

The overall energy use ratio (OEUR) was then determined as the ratio of the energy output intensity to the energy input intensity (Equation 8). It is assumed that, if the OEUR is greater than 1 , then the production system is gaining energy, otherwise it is losing energy.

$$
O E U R=\frac{e_{O}}{e_{I}}
$$

where:

OEUR = Overall energy use ratio, dimensionless

$\mathrm{e}_{0}=$ Energy output intensity, $\mathrm{MJ} \mathrm{ha}^{-1}$

$\mathrm{e}_{\mathrm{I}}=$ Energy input intensity, $\mathrm{MJ}$ ha-1

Energy equivalent value of $109 \mathrm{MJ} \mathrm{kg}^{-1}$ was used to represent the embodied energy in a piece of equipment as reported by Pimentel (1992). He further reported that the average energy value of $109 \mathrm{MJ} \mathrm{kg}^{-1}$ of weight of machinery includes $62.8 \mathrm{MJ} \mathrm{kg}^{-1}$ for steel production; $8.4 \mathrm{MJ} \mathrm{kg}^{-1}$ for the fabrication of parts and assembly; and $37.7 \mathrm{MJ} \mathrm{kg}^{-1}$ for repairs and maintenance. All practices requiring fossil fuel were evaluated with diesel and petrol as the energy sources. The energy associated with fuel use was $47.8 \mathrm{MJ} \mathrm{L}^{-1}$ and $46.3 \mathrm{MJL}^{-1}$ for diesel and petrol fuels, respectively (Pimentel, 1992). This includes estimates for engine oil, grease, manufacture and transportation to the farm as reported by Bridges \& Smith (1979). The human energy required to perform any operation or practice is based on the number of labourers required to perform the operation and the field capacity of the machine. In this study, the labour input in terms of manual energy was evaluated at $1.96 \mathrm{MJh}^{-1}$ (Norman, 1978; Pimentel, 1992). Chemical fertilizers, farmyard manure and pesticides are main sources for chemical energy inputs. ). The total chemical fertilizer input was calculated using energy equivalent values were assumed to be 78.1, 17.4 and $13.7 \mathrm{MJ} / \mathrm{kg}$ for nitrogen $(\mathrm{N})$, phosphorus $\left(\mathrm{P}_{2} \mathrm{O}_{5}\right)$ and potassium $\left(\mathrm{K}_{2} \mathrm{O}\right)$ respectively (Mudahar \& Hignett, 1987). These are the energy requirements for producing and transporting commercial fertilizers. The average energy inputs for the production of the active ingredients of herbicides, insecticides and fungicides were assumed to be 255, 185 and $97 \mathrm{MJkg}^{-1}$, respectively (Black, 1971; Hatirli et al., 2006). An average energy coefficient $\left(B_{s}\right)$ of $14.7 \mathrm{MJ} \mathrm{kg}^{-1}$ for millet seeds was used (Abubakar \& Ahmad, 2010)

\section{Analysis and discussions of energy input-output in millet production}

Energy analysis was performed based on field operations in millet production such as land clearing, tillage, planting, weeding, farmyard manure/fertilizer application, pesticides application, harvesting and threshing. Operational energy used in form of the direct (fuel and human labour or animal power) and indirect (machinery, farmyard manure, fertilizer, 
pesticide, and seed) energy sources involved in the production process were computed. The analysis of the data collected with respect of the millet reduction in the study area was reported. The major issue of concern is that farmers use more energy to increase output but they do not have enough knowledge on most efficient energy inputs to use. Thus, an inputoutput energy analysis provides farmers and policy makers an opportunity to evaluate economic intersection of energy use. Direct and indirect types of energy are required for agricultural production. Energy input-output relation analysis is usually used to evaluate the efficiency and environmental impacts of the production systems. On the other hand, the energy use ratios in agricultural production are closely related with production techniques, quantity of input, yield level and environmental factors. It was also reported that large farms used energy in the best possible way to achieve maximum yield than the small size farm (Sarkar, 1997; Shearer et al., 1981; Sims et al., 2006).

\begin{tabular}{|c|c|c|c|c|}
\hline \multirow[t]{2}{*}{ Field operation } & \multirow{2}{*}{$\begin{array}{c}\text { Energy } \\
\text { resource input } \\
(\mathrm{MJ})\end{array}$} & \multicolumn{3}{|c|}{$\begin{array}{l}\text { Energy resource Input for different farmer } \\
\text { groups }\left(\mathrm{MJ} \mathrm{ha} \mathrm{h}^{-1}\right)\end{array}$} \\
\hline & & Group I & Group II & Group III \\
\hline \multirow{4}{*}{ Land Clearing } & $\mathrm{ME}_{\text {labour }}$ & 130 & 220 & 70 \\
\hline & $\mathrm{E}_{\mathrm{DA}}$ & 75 & 30 & Nil \\
\hline & $S_{\text {DFE }}$ & Nil & 35 & 65 \\
\hline & $\mathrm{S}_{\text {INDME }}$ & Nil & 65 & 145 \\
\hline \multirow{4}{*}{ Tillage } & $\mathrm{ME}_{\text {labour }}$ & 400 & 65 & 40 \\
\hline & $\mathrm{E}_{\mathrm{DA}}$ & 320 & 180 & Nil \\
\hline & $S_{\text {DFE }}$ & Nil & 820 & 1600 \\
\hline & SINDME & Nil & 550 & 700 \\
\hline \multirow{4}{*}{ Planting } & $\mathrm{ME}_{\text {labour }}$ & 450 & 145 & 135 \\
\hline & $\mathrm{E}_{\mathrm{DA}}$ & 70 & 120 & Nil \\
\hline & $\mathrm{S}_{\mathrm{DFE}}$ & Nil & 320 & 600 \\
\hline & $S_{\text {INDME }}$ & Nil & 150 & 250 \\
\hline \multirow{4}{*}{ Weeding } & ME $_{\text {labour }}$ & 750 & 435 & 115 \\
\hline & $\mathrm{E}_{\mathrm{DA}}$ & 35 & 25 & 220 \\
\hline & $\mathrm{S}_{\mathrm{DFE}}$ & Nil & 120 & 180 \\
\hline & $S_{\text {INDME }}$ & Nil & 240 & 425 \\
\hline \multirow{4}{*}{$\begin{array}{c}\text { Farmyard } \\
\text { manure/Fertilizers } \\
\text { application }\end{array}$} & $\mathrm{ME}_{\text {labour }}$ & 350 & 65 & 30 \\
\hline & $\mathrm{E}_{\mathrm{DA}}$ & 180 & 110 & Nil \\
\hline & $S_{D F E}$ & Nil & 125 & 150 \\
\hline & SINDME & Nil & 250 & 340 \\
\hline \multirow{4}{*}{$\begin{array}{l}\text { Pesticides } \\
\text { application }\end{array}$} & $\mathrm{ME}_{\text {labour }}$ & 320 & 115 & 45 \\
\hline & $\mathrm{E}_{\mathrm{DA}}$ & 110 & Nil & Nil \\
\hline & $S_{D F E}$ & Nil & 45 & 120 \\
\hline & $S_{\text {INDME }}$ & Nil & 120 & 180 \\
\hline \multirow{4}{*}{$\begin{array}{l}\text { Harvesting and } \\
\text { Threshing }\end{array}$} & ME $_{\text {labour }}$ & 540 & 350 & 150 \\
\hline & $\mathrm{E}_{\mathrm{DA}}$ & 215 & 90 & Nil \\
\hline & $\mathrm{S}_{\mathrm{DFE}}$ & $\mathrm{Nil}$ & 75 & 145 \\
\hline & $\mathrm{S}_{\text {INDME }}$ & Nil & 250 & 415 \\
\hline
\end{tabular}

Table 1. Mean values of energy resource input for various field operations for different farmer groups 


\subsection{Energy use pattern}

Table 1 showed the computed values of energy resource input for various field operations for different farmer groups. The study revealed that the least amount of energy input was during land clearing for the entire three farmer group (Figure 1a-c). Actually the amount of energy needed for this operation is generally low because all the farmlands have been previously cultivated. There was nothing much to be done apart from burning and collecting dry plant residues and grasses. Tillage and weeding operational activities consumed the highest energy input values for the three groups of the farmers. This could be due to the highly intensive and excessive energy use during soil breaking by tillage implements and weeding was mostly repeated manually since fewer chemicals were used by the farmers in controlling weeds. This findings is in agreement with the result reported by Nuray, (2009); Umar, (2003); Leach, (1975) and Lockeretz et al., (1978). Group I farmers consumed $20 \%$ of the energy used on weeding operation, $19 \%$ on harvesting and threshing activities with $5 \%$ energy used on land clearing. Energy used by Group II and III farmers include $33 \%$ for tillage, $17 \%$ for weeding and $7 \%$ for land clearing; and 38\% for tillage, $16 \%$ for planting and $5 \%$ for land clearing respectively. Results suggest that for the group with big size farm ( $\geq 5$ hectares), tillage operation consumes the highest energy whereas for group with farm size ( $\leq 1$ hectare), weeding engulfs more energy. This is similar with research reported by Shahin et al., (2008); Pimentel \& Pimentel, 1996 (1996) and Walsh et al., (1998), whose agreed that the energy consumption depends on farm size and level of production activities.

Duncan multiple range test (DMRT) for the mean comparison of the resource input for various field operations for different farmer groups (Table 2). Result shows that all means are statistically different at $95 \%$ confidence level. A linear relationship between the total energy input and output from the multiple linear regression analysis conducted for the various farmer groups with value of $\mathrm{R}^{2}=0.97$. This indicates that millet crop yield is directly dependent on the energy resource input.

Means with the same letter are not statistically different at the $5 \%$ level of significance Figure $2 \mathrm{a}$ and $\mathrm{b}$ depicts the average total energy inputs from based on the energy sources during the millet production from the various farmer groups. Manual and fuel energy were the main contributor of the direct energy for farmers in group I and Group III respectively (Figure 2a). From the indirect energy sources fertilizer had the highest contribution followed by pesticides and machinery energy sources (Figure $2 b$ ).

\begin{tabular}{|c|c|c|c|c|c|c|c|}
\hline \multirow{2}{*}{$\begin{array}{c}\text { Farmer } \\
\text { groups }\end{array}$} & \multicolumn{7}{|c|}{ Field operational energy consumption (MJ ha-1) } \\
\cline { 2 - 8 } & $\begin{array}{c}\text { Land } \\
\text { Clearing }\end{array}$ & Tillage & Planting & Weeding & $\begin{array}{c}\text { Farmyard } \\
\text { manure/Fertilize } \\
\text { rs application }\end{array}$ & $\begin{array}{c}\text { Pesticides } \\
\text { application }\end{array}$ & $\begin{array}{c}\text { Harvesting } \\
\text { and } \\
\text { Threshing }\end{array}$ \\
\hline Group I & $205^{\mathrm{a}}$ & $720^{\mathrm{b}}$ & $520^{\mathrm{c}}$ & $785^{\mathrm{d}}$ & $530^{\mathrm{e}}$ & $430^{\mathrm{f}}$ & $755 \mathrm{~g}$ \\
\hline Group II & $350^{\mathrm{a}}$ & $1615^{\mathrm{b}}$ & $735^{\mathrm{c}}$ & $820^{\mathrm{d}}$ & $550^{\mathrm{e}}$ & $280^{\mathrm{f}}$ & $515 \mathrm{~g}$ \\
\hline $\begin{array}{c}\text { Group } \\
\text { III }\end{array}$ & $280^{\mathrm{a}}$ & $2340^{\mathrm{b}}$ & $985^{\mathrm{c}}$ & $940^{\mathrm{d}}$ & $490^{\mathrm{e}}$ & $345^{\mathrm{f}}$ & $710 \mathrm{~g}$ \\
\hline
\end{tabular}

Table 2. Duncan multiple range tests for mean comparison of energy resource input for various field operations for different farmer groups 


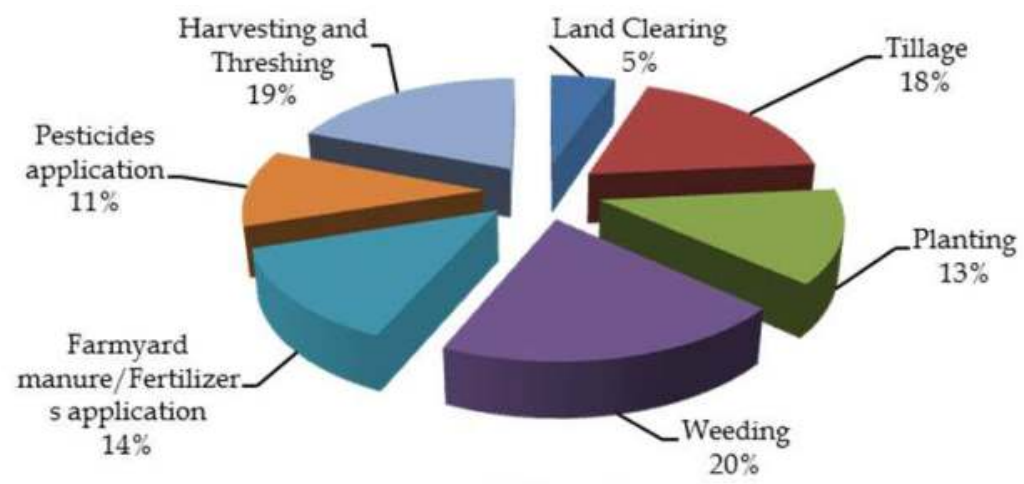

(a) Group I

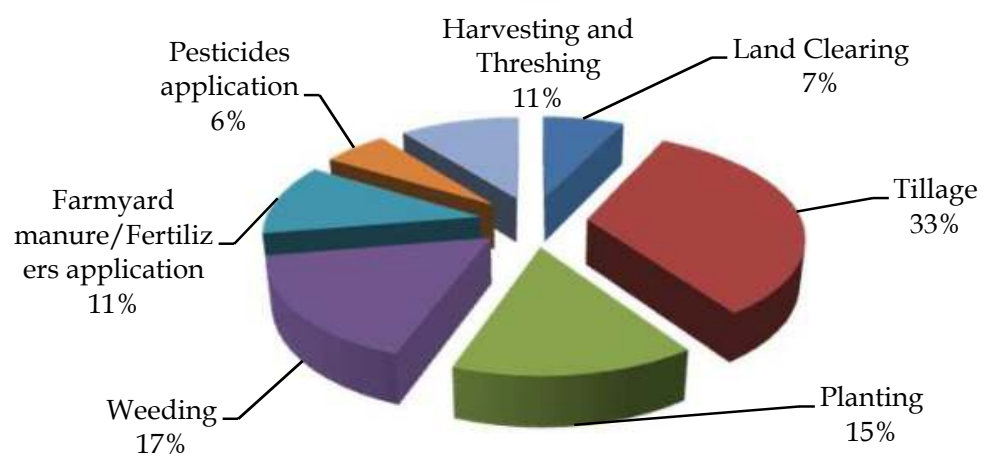

(b) Group II

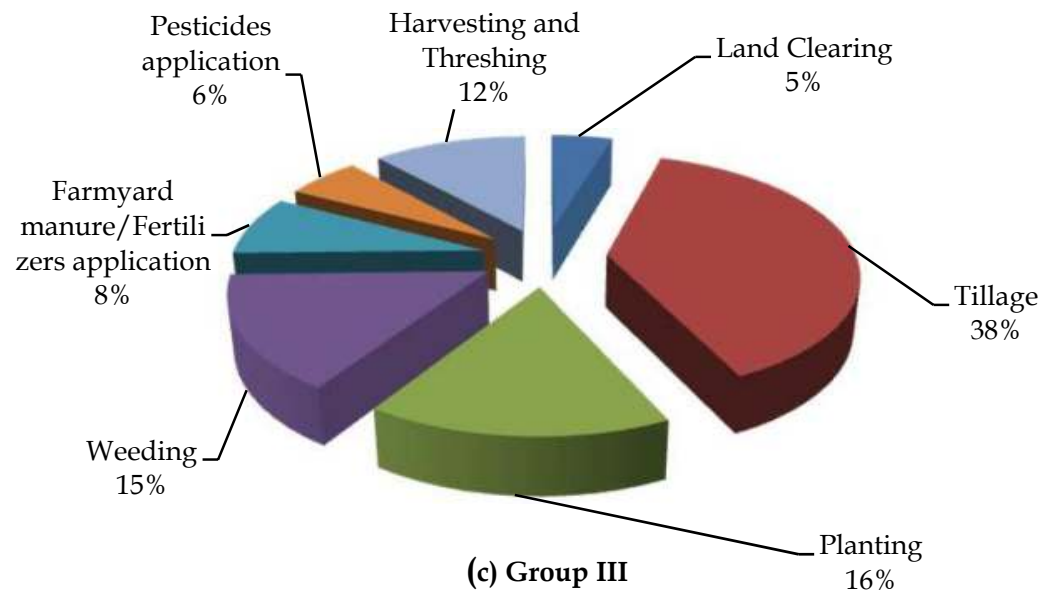

Fig. 1. $a, b$ and C. Percentage mean total of energy input per field operation for various farmers group (a) Group I, (b) Group II and (c) Group III 


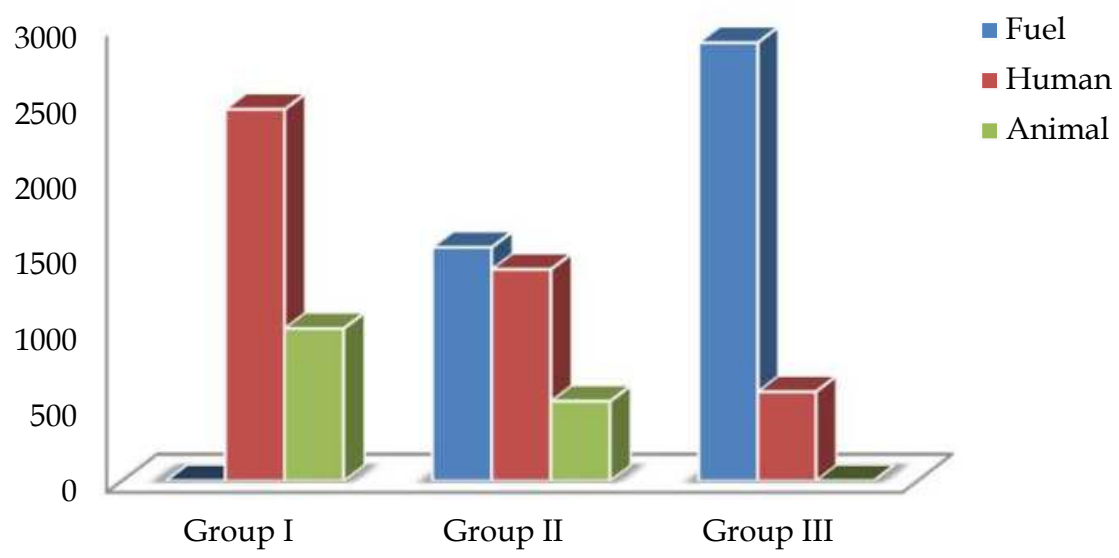

(a) Direct energy input

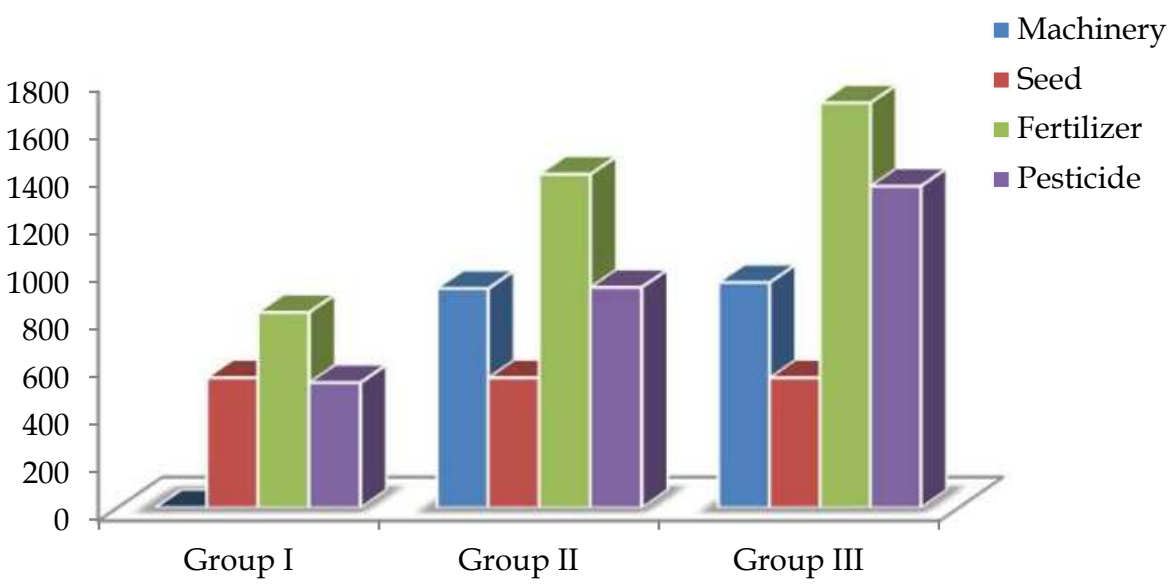

(b) Indirect energy input

Fig. 2. a. and b. Average total energy inputs based on sources (a) direct energy input, (b) indirect energy input for various farmer groups

\subsection{Overall energy use ratio}

The overall energy use ratio (OEUR) was determined from the ratio of total energy output to the total energy input (Table 3). The farmer group with OEUR value greater than 1 indicates the millet production system is gaining energy or else that it is losing energy. Result demonstrates that group II farmers have shown efficient use of energy resources. This could be because they have been using all the sources of the energy during their millet production processes. The lowest overall energy use ratio value obtained was 0.8 for group I farmers. 
This shows losing of energy use or low efficient level of energy usage in the course of millet production. The reason is obvious since the farmers in this group use manual labour from human and animal in producing the millet which was laborious and time consuming, a scenario similar to the finding of Haque et al., (2000); Pimentel, (2009); Mohammadi \& Omid, 2010) (2010) and Tolga et al., (2009) who conducted and reported similar work for different types of crops in different parts of the world.

\begin{tabular}{|l|l|l|l|}
\hline Energy input and output in all field & \multicolumn{3}{|l|}{ Farmer groups } \\
\cline { 2 - 4 } operations & Group I & Group II & Group III \\
\hline Total energy input $\left(\mathrm{e}_{\mathrm{I}}\right)\left(\mathrm{MJ} \mathrm{ha}^{-1}\right)$ & 3945 & 4845 & 6090 \\
\hline Total energy output (eo) (MJ ha $\left.{ }^{-1}\right)$ & 3156 & 12597 & 12789 \\
\hline Overall energy use ratio (OEUR) & 0.8 & 2.6 & 2.1 \\
\hline
\end{tabular}

Table 3. Total energy inputs, energy outputs and energy use ratio

\section{Conclusions}

The study reported the pattern of energy use for millet production with selected farmers. Production energy indicators were evaluated using data collected from a structural questionnaire and published literatures. Result revealed the major energy sources were manual labour, animal draft and fuel energy for the direct energy and also farmyard manure, pesticides, machinery and seed for the indirect energy. Soil tillage and weeding operations were the production activities that consumed most of the energy intense operation whereas land clearing operation requires the least energy input for the entire farmer groups. However, it was observed that the cost of energy use per unit area decreased with increase of farm size. This would serve as a key guide for small size millet producers in the study area during policy making, planning and action taken as well as the government or any other stakeholder of millet production around the globe.

\section{References}

Abubakar, M. S. \& Ahmad, D. (2010). Pattern of energy consumption in millet production for selected farms in Jigawa, Nigeria. Australian Journal of Basic and Applied Sciences, $4(4), 665-672$.

Ahmad, B. (1994). Energetics of major crops in mixed cropping system. Agricultural Mechanization for Africa, Latin America and Asia 25(3), 52-54.

Alam, M. S., Alam, M. R. \& Islam, K. K. (2005). Energy flow in agriculture: Bangladesh. American Journal of Environmental Science, 1(3), 213-220.

Andrews, D. J. \& Kumar, K. A. (1992). Pearl millet for food, feed and forage. Advance Agronomy, 48(89-139).

Black, J. N. (1971). Energy relations in crop production a preliminary survey. Annals of Applied Biology, 67(2), 272-278.

Bockari-Gevao, S. M., Wan Ishak, W. I., Azmin, Y. \& Chan, C. W. (2005). Analysis of energy consumption in lowland rice-based cropping system of Malaysia. Songklanakarin Journal of Science and Technology, 27(4), 819-826.

Bridges, T. C. \& Smith, E. M. (1979). A method for determining the total energy input for agricultural practices. Transactions of the ASAE, 781-784. 
Canakci, M. \& Akinci, I. (2006). Energy use pattern analyses of greenhouse vegetable production. Energy, 31(8-9), 1243-1256.

FAO. (1996). Production yearbook. Rome, Italy: Food and Agriculture Organisation.

Fluck, R. C. (1985). Energy sequestered in repairs and maintenance of agricultural machinery. Transactions of the ASAE, 28(3), 738-744.

Haque, M. A., Umar, B. \& Kawuyo, U. A. (2000). A preliminary survey on the use of animal power in agricultural operations in Adamawa state, Nigeria. Outlook on agriculture, 29(2), 123-127.

Hatirli, S. A., Ozkan, B. \& Fert, C. (2006). Energy inputs and crop yield relationship in greenhouse tomato production. Renewable Energy, 31(4), 427-438.

Hoeppner, J. W., Entz, M. H., McConkey, B. G., Zentner, R. P. \& Nagy, C. N. (2006). Energy use and efficiency in two Canadian organic and conventional crop production systems. Renewable Agriculture and Food Systems, 21(01), 60-67.

Jekayinfa, S. O. \& Bamgboye, A. I. (2007). Development of equations for estimating energy requirements in palm-kernel oil processing operations. Journal of Food Engineering, 79(4), 322-329.

Khambalkar, V., Pohare, J., Katkhede, S., Bunde, D. \& Dahatonde, S. (2005). Energy and economic evaluation of farm operations in crop production. Journal of Agricultural Science, 2(4), 15-22.

Kizilaslan, H. (2009). Input-output energy analysis of cherries production in Tokat Province of Turkey. Applied Energy, 86(7-8), 1354-1358.

Leach, G. (1975). Energy and food production. Food Policy, 1(1), 62-73.

Lockeretz, W., Shearer, G., Klepper, R. \& Sweeney, S. (1978). Field crop production on organic farms in the Midwest. Journal of Soil and Water Conservation, 33(3), 130-134.

Mohammadi, A. \& Omid, M. (2010). Economical analysis and relation between energy inputs and yield of greenhouse cucumber production in Iran. Applied Energy, 87, 191-196.

Mudahar, M. S. \& Hignett, T. P. (1987). Energy requirements, technology and resources in fertilizer sector In Plant nutrition and pest control: Energy in world agriculture (Vol. 2): Elsevier.

Norman, M. J. T. (1978). Energy inputs and outputs of subsistence cropping systems in the tropics. Agro-ecosystems, 4(3), 355-366.

Nuray, K. (2009). Energy use and inputs-outputs energy analysis for apple production in Turkey. Journal of Food, Agriculture and Environment, 7(2), 419-423.

Ozkan, B., Akcaoz, H. \& Fert, C. (2004). Energy input-output analysis in Turkish agriculture. Renewable Energy, 29, 39-51.

Pimentel, D. (1992). Energy inputs in production agriculture. Amsterdam: Elsevier.

Pimentel, D. (2009). Energy inputs in food crop production in developing and developed nations. Energies, 2(1), 1-24.

Pimentel, D. \& Pimentel, M. (1996). Energy use in grain and legume production. Food, Energy and Society, 107-130.

Reed, W., Geng, S. \& Hills, F. J. (1986). Energy input and output analysis of four field crops in California1. Journal of Agronomy and Crop Science, 157(2), 99-104.

Sarkar, A. (1997). Energy-use patterns in sub-tropical rice-wheat cropping under short term application of crop residue and fertilizer. Agriculture, Ecosystems \& Environment, 61(1), 59-67. 
Shahin, S., Jafari, A., Mobli, H., Rafiee, S. \& Karimi, M. (2008). Effect of farm size on energy ratio for wheat production: A case study from Ardabil Province of Iran.

Shearer, G., Kohl, D. H., Wanner, D., Kuepper, G., Sweeney, S. \& Lockeretz, W. (1981). Crop production costs and returns on Midwestern organic farms: 1977 and 1978. American Journal of Agricultural Economics, 63(2), 264-269.

Sims, R. E. H., Hastings, A., Schlamadinger, B., Taylor, G. \& Smith, P. (2006). Energy crops: current status and future prospects. Global Change Biology, 12(11), 2054-2076.

Singh, H., Mishra, D. \& Nahar, N. M. (2002). Energy use pattern in production agriculture of a typical village in arid zone of India - Part I. Energy Conversion and Management, 43(16), 2275-2286.

Singh, H., Mishra, D. \& Nahar, N. M. (2003). Energy use pattern in production agriculture of a typical village in arid zone of India - Part II. Energy Conversion and Management, 44(7), 1053-1067.

Singh, H., Singh, A. K., Kushawaha, H. L. \& Singh, A. (2007). Energy consumption pattern of wheat production in India. Energy 32(8), 1848-1854.

Singh, S. \& Mittal, J. P. (1992). Energy in production agriculture. New Delhi, India: Mittal Publications.

Singh, S., Verma, S. R. \& Mittal, J. P. (1997). Energy requirements for production of major crops in India. Agricultural Mechanization for Africa, Latin America and Asia, 28(4), 1317.

Stout, B. A. (1990). Handbook of energy for world agriculture. London: Elsevier Applied Science.

Tolga, T., Bahattin, C. \& Vardar, A. (2009). An analysis of energy use and input costs for wheat production in Turkey. Journal of Food, Agriculture and Environment, 7(2), 352356.

Umar, B. (2003). Comparison of manual and manual-cum-mechanical energy uses in groundnut production in a semi-arid environment. Agricultural Engineering International: CIGR Journal.

Walsh, M. E., De La Torre Ugarte, D., Slinsky, S., Graham, R. L., Shapouri, H. \& Ray, D. (1998). Economic analysis of energy crop production in the US--location, quantities, price and impacts on traditional agricultural crops. Bioenergy 98: Expanding Bioenergy Partnerships, 2, 1302-1310. 


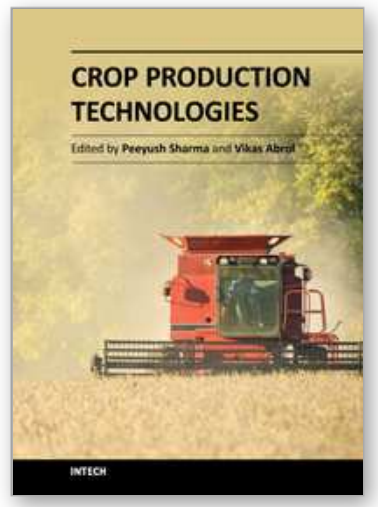

\author{
Crop Production Technologies \\ Edited by Dr. Peeyush Sharma
}

ISBN 978-953-307-787-1

Hard cover, 276 pages

Publisher InTech

Published online 05, January, 2012

Published in print edition January, 2012

Crop production depends on the successful implementation of the soil, water, and nutrient management technologies. Food production by the year 2020 needs to be increased by 50 percent more than the present levels to satisfy the needs of around 8 billion people. Much of the increase would have to come from intensification of agricultural production. Importance of wise usage of water, nutrient management, and tillage in the agricultural sector for sustaining agricultural growth and slowing down environmental degradation calls for urgent attention of researchers, planners, and policy makers. Crop models enable researchers to promptly speculate on the long-term consequences of changes in agricultural practices. In addition, cropping systems, under different conditions, are making it possible to identify the adaptations required to respond to changes. This book adopts an interdisciplinary approach and contributes to this new vision. Leading authors analyze topics related to crop production technologies. The efforts have been made to keep the language as simple as possible, keeping in mind the readers of different language origins. The emphasis has been on general descriptions and principles of each topic, technical details, original research work, and modeling aspects. However, the comprehensive journal references in each area should enable the reader to pursue further studies of special interest. The subject has been presented through fifteen chapters to clearly specify different topics for convenience of the readers.

\title{
How to reference
}

In order to correctly reference this scholarly work, feel free to copy and paste the following:

Mohammed Shu'aibu Abubakar (2012). Energy Use Pattern in Millet Production in Semi-Arid Zone of Nigeria, Crop Production Technologies, Dr. Peeyush Sharma (Ed.), ISBN: 978-953-307-787-1, InTech, Available from: http://www.intechopen.com/books/crop-production-technologies/energy-use-pattern-in-millet-production-insemi-arid-zone-of-nigeria

\section{INTECH}

open science | open minds

\section{InTech Europe}

University Campus STeP Ri

Slavka Krautzeka 83/A

51000 Rijeka, Croatia

Phone: +385 (51) 770447

Fax: +385 (51) 686166

\section{InTech China}

Unit 405, Office Block, Hotel Equatorial Shanghai

No.65, Yan An Road (West), Shanghai, 200040, China 中国上海市延安西路65号上海国际贵都大饭店办公楼 405 单元

Phone: +86-21-62489820

Fax: +86-21-62489821 
www.intechopen.com 
(C) 2012 The Author(s). Licensee IntechOpen. This is an open access article distributed under the terms of the Creative Commons Attribution 3.0 License, which permits unrestricted use, distribution, and reproduction in any medium, provided the original work is properly cited. 